\title{
Vesten ruster sig overfor Rusland
}

\author{
Af Ole Bang Nielsen i Bruxelles
}

Præsident Putins indlemmelse af Krim i Rusland og den hårde kurs overfor Ukraine kan hurtigt vise sig at være en pyrrhussejr. Krisen har nemlig styrket viljen i EU til for første gang at reagere samlet og strategisk på Ruslands aggression.

Det nytter ikke noget at forsøge at være for kammeratlige med russerne, lød rådet fra den amerikanske diplomat og Ruslands-kender George Kennan, der tilbragte flere år på den amerikanske ambassade i Moskva i 1930erne og under Anden Verdenskrig.

"Don't act chummy with them", sagde Kennan til de vestlige ledere under den første Berlin-krise i 1948, da Sovjet-Rusland forsøgte at blokere adgangen til Vest-Berlin for de Vest-allierede. Kennan blev den sikkerhedspolitiske arkitekt bag den såkaldte inddæmningsstrategi, som de Vest-allierede slog ind på under Den Kolde Krig.

"Den tålmodige ihærdighed, hvormed Sovjetunionen forfølger sine mål, betyder, at det ikke kan modarbejdes effektivt ved sporadiske handlinger, der er udslag af den demokratiske opinions luner, men kun ved en intelligent, langfristet politik, der er lige så standhaftig i sin målsætning og alsidig og opfindsom i sine metoder som Sovjetunionen", skrev George Kennan i tidsskriftet Foreign Affairs. Han advarede kraftigt imod, at man kom nogle vegne med Moskva gennem det personlige diplomati, som vestlige politikere den gang troede, at de kunne anvende overfor Josef Stalin.

Men det er præcis, hvad Europa og USA har forsøgt i de sidste 30 år, siden Den Kolde Krig begyndte at ebbe ud med Mikhail Gorbatjovs overtagelse af ledelsen i Moskva. Siden har vestlige ledere haft en forestilling om, at de gennem personligt diplomati og ved at optræde "chummy" over for skiftende russiske ledere kunne forankre Rusland i vestligt demokrati og markedsøkonomi.

Længe så det ellers ud som en farbar vej, og der var succesfyldte partnerskaber. Helmut Kohls med Gorbatjov, der var med til at sikre Tysklands genforening. Siden Bill Clintons med Boris Jeltsin i 1990erne. Og selv da Vladimir Putin kom til og begyndte at slå på de mere nationalistiske strenge, forsøgte vestli-

Ole Bang Nielsen ег journalist og har siden 1990 arbejdet som udenrigspolitisk journalist i Bruxelles. Han har blandt andet rapporteret for Berlingske Tidende og Dagbladet Information. 
ge politiske ledere som George W. Bush og Gerhard Schröder ihærdigt at skabe et "særligt" forhold til Rusland.

Med den seneste krise om Krim synes den sidste illusion imidlertid at være knust om, at Vesten og Rusland på sigt har fælles interesser.

For første gang siden Anden Verdenskrig har et land på det europæiske kontinent med brug af magt taget en del af et andet land til sig. Samt ladet hånt om en international aftale - det såkaldte Budapest-memorandum fra 1994, hvor de vestlige stormagter og Rusland i fællesskab skrev under på at garantere Ukraines territoriale integritet.

Putins greb efter Krim har fået alarmklokkerne til at ringe fra Østersøen til Kaukasus. Tidligere Sovjet-republikker som Ukraine, Georgien og Moldavien må nu frygte for deres fortsatte selvstændighed. Og selv de baltiske lande, som slap væk fra Rusland i tide, er begyndt at spekulere kraftigt over, om deres medlemskab af EU og NATO er nok til at beskytte dem.

Efter at have høstet fredsdividenden i snart 25 år efter Berlin-murens fald ligner det et mareridt for Europa, at der nu igen er et aggressivt Rusland på den østlige flanke. Så det er ikke underligt, at europæiske aviser i de seneste uger har været fyldt med dystre advarsler om en kommende ny "kold krig".

Så galt går det næppe. Den rigtige Kolde Krig var i bund og grund et ideologisk opgør mellem to forestillinger om, hvordan verden skal indrettes. Og en "krig" der blev ført med alle midler - militære, politiske, økonomiske, sågar kulturelle over hele kloden.

Sovjet-kommunismen blev - på trods af sine fejl og svagheder - i nogle årtier opfattet som et reelt alternativ til den vestlige model med demokrati og markedsøkonomi. Ikke mindst i det, som vi en gang kaldte Den Tredje Verden. Det er lidt svært at få øje på nogen ideologisk linje i Vladi- mir Putins måde at styre Rusland på. Og i hvert fald ikke nogen ideologi, der kan eksporteres eller vække ret megen begejstring udenfor Ruslands egne grænser.

Analysen blandt diplomater i EU og NATO går da også på, at vi snarere står over for et klassisk geopolitisk opgør med Rusland. Et opgør, som dybest set går ud på at definere grænserne for henholdsvis EU's og Ruslands interessesfærer.

\section{EU's store chance}

I medierne har der været mange rapporter om, at EU står magtesløst over for Rusland, og at EU-landene som sædvanligt er splittede om, hvor hårdt man skal konfrontere Putin - især på spørgsmålet om sanktioner.

Umiddelbart ser Vladimir Putin da også ud som den stærke mand og vinderen i opgøret. På kun en uge og næsten uden at affyre et skud overtog Rusland kontrollen med Krim-halvøen. Putin kunne lade sig hylde i Sankt-Georg salen i Kreml som politikeren, der var kommet det russiske mindretal i Ukraine til undsætning og som havde formået at sætte Vest-magterne på plads.

Men det er en sandhed med modifikationer. For Ruslands overraskende hårde reaktion på den politiske omvæltning i Ukraine er ved at åbne europæernes øjne for, at der skal gås helt anderledes håndfast til Rusland i de kommende år. Og ikke mindst at EU har brug for at styrke sin rolle som strategisk, global spiller - også med militære midler.

Udviklingen i Ukraine er en udfordring, men også en enestående historisk chance for EU til at udvide sin magt og sin rolle.

"Vi taler i Ukraine om de første mennesker, der har ofret deres politiske liv for Europas integration", sagde den polske premierminister Donald Tusk, da dødstallet steg under demonstrationerne i Kijev. "Der er sket tragiske begivenheder, men i fremtiden vil det hele blive set som et håb for Ukraine".

I Bruxelles betragtes begivenhederne $\mathrm{i}$ Ukraine i de seneste måneder derfor som en triumf for EU's "bløde magt". 
For kun tre måneder siden så det ud som, at EU var blevet udmanøvreret af Moskva, efter at det russiske pres fik den daværende regering i Kijev til at afvise tilbuddet om en udvidet handels- og samarbejdsaftale med EU. Flere års forhandlinger mellem EU og Ukraine var tabt på gulvet, og Putin synes at have sat sig igennem.

Men hovedparten af den ukrainske befolkning ville det som bekendt anderledes og væltede styret i Kijev, hvorefter den nye regering underskrev de første dele af partnerskabsaftalen med EU.

Dermed hviler der også et særligt ansvar på EU. "Vi har forført Ukraine", som en højtstående diplomat i Bruxelles udtrykker det. Noget egentligt EU-medlemskab er der ikke udsigt til foreløbig, men interessant nok har EU åbnet for muligheden gennem en formulering om, at "partnerskabsaftalen ikke er den endelige afslutning på Ukraines forhold til den Europæiske Union”.

\section{Øjenåbner i EU}

For EU drejer det sig nu om at sikre resten af Ukraines territoriale integritet. Krim regnes i første omgang for "tabt" til Rusland. Men selve Ukraine med dets store potentielle landbrugs- og industri-ressourcer står stadig som en langt vigtigere gevinst $\mathrm{i}$ opgøret med Rusland.

Krim-krisen har på den måde været en øjenåbner for en række af EU's politikere, der er begyndt at tale i et langt mere militant sprogbrug. EU's beslutninger om at indføre sanktioner mod Rusland, selv om det kan komme til at gøre ondt på Europas egen økonomi, kom overraskende hurtigt i stand. Samtidig har EU på flere topmøder brugt tid på at drøfte en mere strategisk indgang til, hvordan man skal tackle Putins Rusland.

Hvor hvert land tidligere fulgte sine egne snævre økonomiske interesser i forholdet til Rusland - herunder at sikre forsyning af den vigtige naturgas og lukrative industriog våbenordrer - er der ifølge diplomater og politiske iagttagere i Bruxelles skabt en ny beslutsomhed om, at man denne gang skal holde sammen.

"Der tales nu om målene på længere sigt", siger Jan Techau, leder af Carnegie Endowment tænketanken i Bruxelles. Han påpeger især, at EU er begyndt at udtænke en langvarig energistrategi, der skal mindske Europas afhængighed af Ruslands naturgas og olie (og i øvrigt også af diverse lande i Mellemøsten).

Strategien omfatter blandt andet, at EU målbevidst skal gå ind og udnytte skifergas, som USA har gjort i de seneste år. Af miljømæssige årsager har EU holdt sig tilbage på dette punkt. Men især Polen og andre af de centraleuropæiske lande, som er yderst afhængige af Ruslands energi, skubber på for at få gang i udnyttelsen af skifergassen.

Et andet punkt er udviklingen af EU's militære rolle, hvor man på et topmøde i december allerede tog væsentlige skridt til at styrke det spæde rustningssamarbejde, bl.a. med at udvikle det første europæiske dronesystem. Samtidig blev det endeligt besluttet at sætte ord bag de mange planer om at have militære kampgrupper parat.

Mens USA tidligere så med stor skepsis på udviklingen af en mere uafhængig europæisk forsvarspolitik, er der under præsident Barack Obama sket et afgørende skifte.

"Tidligere ønskede USA at have fuld kontrol over, hvad europæerne foretog sig militært. Nu lyder kravet tværtimod fra Washington, at europæerne bør tage sig sammen og påtage sig større opgaver”, påpeger den franske sikkerhedspolitiske kommentator Francois Heisbourg.

Samtidig har USA skåret ned på de militære ressourcer, man hidtil har afsat til Europa og Afrika. Det amerikanske militær skal spare godt en billion dollars om året. "Vi har brug for at arbejde sammen som næsten aldrig før", lød det nærmest undskyldende fra NATO's øverste militære kommandør, SACEUR, den amerikanske luftvåbensgeneral Philip Breedlove, da han sidste efterår 
måtte bebude en 20 procents nedskæring på Europa- og Afrika-kommandoen.

De vellykkede europæisk ledede interventioner i Libyen og Mali har skabt en ny betydelig transatlantisk forståelse efter skænderierne under Bush-årene. Frankrig gik forrest i de to aktioner, og den tid er for længst glemt, da amerikanske politikere beskrev franskmændene som "cheese-eating surrender monkeys" - på dansk vel nærmest "oste-ædende svæklinge" - da Frankrig sagde nej til at deltage i Irak-invasionen i 2003.

Præsident Francois Hollandes socialistiske regering fremlagde sidste år en hvidbog om landets forsvar, som understregede behovet for, at fransk militær kan gribe ind globalt. Og det franske forsvar har i modsætning til f.eks det britiske været i stand til næsten at bevare sine i forvejen høje bevillinger.

\section{Tysklands særlige rolle}

Men den politisk mest interessante udvikling internt i EU på det sikkerhedspolitiske område er i gang i Tyskland. Og som på næsten alle andre områder i EU er Tyskland også nøglelandet, når det gælder forholdet til Rusland og en udvikling af EU's geopolitiske rolle.

Tyske regeringer har i de sidste 40 år holdt fast i den særlige "Ost-politik", som første gang blev udviklet af daværende forbundskansler Willy Brandt tilbage i begyndelsen af 1970erne med normaliseringen af forholdet til DDR og Sovjetunionen og en forsoning med Polen, der blev symboliseret ved hans berømte knæfald i Warszawa foran mindesmærket for de myrdede jøder i ghettoen.

Ost-politikken går - noget forenklet - ud på, at Tyskland har et særligt historisk og kulturelt forhold til Rusland, og at Tyskland derfor bedre er i stand til at forhandle med russerne end andre vestlige magter. Gennem årene er Ost-politikken blevet fortsat af skiftende kanslere i Bonn og Berlin, og den har som udgangspunkt haft, at det er muligt at tale fornuftigt med russerne, og at opbygningen af tætte økonomiske bånd vil bidrage til at bringe Rusland tættere på Vesten, også på det politiske plan.

Ost-politikken har som tidligere nævnt haft en række triumfer; herunder den fredelige udgang på Tysklands genforening og den endelige tysk-polske grænsedragning. Samtidig har den været med til at gøre Tyskland til Ruslands vigtigste økonomiske samarbejdspartner og været ganske god for tysk erhvervsliv.

Men under Putin har Ost-politikken været trængt, og der er nu opstået en kraftig intern debat i Tyskland om, hvorvidt den skal fortsætte.

Den tyske forbundskansler Angela Merkels bemærkelsesværdige tale i Forbundsdagen i Berlin under højdepunktet i Krim-krisen, da hun advarede Rusland om, at hvis det fortsatte sin aggression mod Ukraine, ville det blive opfattet som "en trussel mod andre nabolande som vort", er af tyske kommentatorer blevet set som et afgørende skridt væk fra den tidligere bløde kurs over for Rusland.

Som opvokset i Østtyskland har Merkel næppe nogen illusioner om det Rusland, som Vladimir Putin - der i sin tid var KGBofficer i DDR - har skabt. Men andre tyske politikere er også begyndt at skærpe tonen. Før Ukraine-krisen eskalerede holdt både den tyske præsident Joachim Gauck og den socialdemokratiske tyske udenrigsminister Frank-Walter Steinmeier bemærkelsesværdige taler på den årlige sikkerhedspolitiske konference i München i begyndelsen af februar. Her advarede de om, at Tyskland ikke længere kan køre på frihjul sikkerhedspolitisk og overlade de militære opgaver i Europa til Frankrig og Storbritannien.

"Netop på os tyskere hviler der et særligt historisk ansvar," sagde præsident Gauck.

Blandt de øvrige EU- og NATO-allierede venter man derfor spændt på, om Tyskland vil omsætte sine nye holdninger i en mere robust sikkerhedspolitik, end det hidtil har været tilfældet. 
Ikke mindst i de baltiske lande og Polen, hvis udenrigsminister Radoslaw Sikorski allerede sidste år sagde, at hans største frygt ikke var et selvbevidst Tyskland, men et Tyskland som tror, at det kan skjule sig for de store internationale konflikter.

Det har disse lande ifølge den tyske historiker Michael Stürmer gode grunde til. NATOs artikel $5 \mathrm{om}$, at et angreb på et medlemsland skal opfattes som et angreb på alle - den såkaldte musketer-ed - blev udvandet i 2001, da USA sagde nej til de europæiske NATO-allieredes tilbud om hjælp ifølge artikel 5 efter al-Qaedas terrorangreb på New York og Washington.

"Kan østeuropæerne stole herpå? I modsætning til under Den Kolde Krig er der ikke længere nogen automatik i dette spørgsmål”, skrev han i en kommentar i Die Welt. Den hurtige udvidelse af NATO mod Øst og USA's langsomme, men ubønhørlige tilbagetrækning fra Europa har skabt usikkerhed om, hvor langt artikel 5 skal fortolkes, mener han. Og for lande uden for selve NATO, der er koblet på med partnerskabsaftaler som Ukraine, er usikkerheden endnu større.

\section{USA skifter kurs}

Indtil videre har den amerikanske præsident Barack Obama ført en benhård kurs mod Rusland, og USA er gået videre med sanktionerne mod Moskva end EU.

Men den amerikanske Ruslands-politik står over for en lige så radikal ændring som den europæiske. I begyndelsen af sin præsidentperiode forsøgte Obama sig med en ny begyndelse for forholdet til Rusland.

Daværende udenrigsminister Hillary Clinton blev i 2009 sendt af sted til et møde med Ruslands ledelse med et budskab om, at der nu skal "trykkes på en ny knap" i forholdet mellem Rusland og USA. Men der kom ikke meget ud af den såkaldte "reset button", set ud fra et amerikansk synspunkt.

Begivenhederne i Ukraine har samtidig sat en kæp i hjulet på Obamas bestræbelser på at flytte USA's udenrigs- og sikkerhedspolitiske engagement mod Asien. Europa er med Ukraine-krisen vendt frygteligt tilbage i amerikansk politik som et potentielt konflikt-område lige som under Den Kolde Krig. Det var netop Ukraine-krisen, der nærmest tvang Obama til at aflægge sit første officielle besøg hos NATO og EU i Bruxelles i hans præsidentperiode.

Som den tidligere amerikanske Ukraineambassadør William Green Miller har påpeget, så hviler der på grund af Budapestmemorandaet fra 1994 et lige så stort ansvar på USA som på Europa, når det drejer sig om at forsvare Ukraines ret til at eksistere som en selvstændig nation.

"Budapest-memorandaet betød, at Ukraine frivilligt opgav sin atomvåben-styrke -den gang verdens tredje største - mod at sikre sig international hjælp i en konflikt, herunder også fra USA. Ukraine har hele tiden været den demokratisk bedst fungerende af de tidligere Sovjet-republikker", sagde den tidligere diplomat til en amerikansk web-avis. Og det fortjener anerkendelse, mener han.

Hvis man skal tage det lange historiske perspektiv, så er udviklingen i Ukraine i de seneste uger en triumf for Europa, fordi det nu står endeligt klart, at Ukraine kan blive et levedygtigt land igen for første gang siden den nationale katastrofe ved slaget ved Poltova i 1709.

I denne ukrainske by ved floden Dnipro knuste Peter den Store den svenske hær ledet af "krigerkongen" Karl den 12, som i årevis havde forsøgt at påtvinge Rusland et nederlag. Da slaget var overstået om aftenen den 28. Juni, var 9.000 svenske soldater og andre tusinde af deres ukrainske allierede blevet dræbt. Karl den 12. undslap selv kun med nød og næppe og måtte tilbringe de næste fem år i reelt fangenskab hos den osmanniske sultan i Konstantinopel, hvor han havde søgt tilflugt.

Ved Poltova endte Sveriges grandiose ambitioner om at blive en europæisk stormagt. Af de 50.000 mand, som Karl den 12. førte 
ud på de russiske og ukrainske stepper, nåede kun få tusinde tilbage til Sverige.

Men det var en endnu større ulykke for ukrainerne, som endeligt kom under et russisk herredømme, der skulle vare helt fra 1709 til Sovjetunionens sammenbrud i 1991. Ukraine forsvandt væk fra den europæiske bevidsthed på en helt anden måde end deres polske naboer, som vi selv under Den Kolde Krigs mørkeste dage kunne holde en vis forbindelse med.

Selv da Ukraine blev selvstændigt i 1991 blev landet ikke rigtigt taget alvorligt eller betragtet som levedygtigt på sigt i Vesten. EU og NATOs regelmæssige møder med Ukraine foregik trægt og uden nerve. Håbet om virkelige demokratiske og økonomiske reformer efter den "orange revolution" i 2004 fusede for hurtigt ud.

I 2008 besluttede NATO derfor på sit topmøde i Bukarest at skrinlægge enhver forhandling med Ukraine om medlemskab. Især de store europæiske medlemslande som Tyskland, Frankrig og Storbritannien var betænkelige ved at udstede forsvarsgarantier til Ukraine. Man ønskede på det tidspunkt ikke at udfordre Rusland.

Året efter - på et EU-topmøde i Prag blev Ukraine og de øvrige tidligere Sovjet-republikker tilbudt aftaler om et udvidet partnerskab, der skulle erstatte muligheden for et egentligt medlemskab af Den Europæiske Union.

De seneste måneders begivenheder har vendt fuldstændig op og ned på denne situation. Ukrainerne kan ikke længere, som en del af offentligheden i USA og Europa havde for vane, betragtes som "halv-russere", der naturligt hører under Ruslands interessesfære.

Ukrainerne har gennem deres optræden i de seneste uger vist mod og modenhed nok til, at de kan betragtes som "rigtige" europæere.

Som en række kommentatorer har været inde på, så har Vladimir Putin med sin aktion for at sikre Krim en fremtid i Rusland tværtimod været med til at styrke Ukraines mulighed for at overleve som en selvstændig nation.

Et betydeligt antal af det russiske mindretal nemlig dem der bor på Krim - er ude af Ukraines politiske liv, i hvert fald på kortere sigt. Ved det planlagte valg i maj er de politiske kræfter, som ønsker et endeligt brud med Moskva og en tilknytning til EU, derfor næsten sikre på at vinde valget. Også i betragtning af den patriotiske bølge, der skyller gennem Ukraine.

Men endnu vigtigere er det som sagt, at Putins chokerende frække og brutale greb om Krim, kan skabe en ny beslutsomhed i Europa om at udvikle EU's udenrigs- og forsvarspolitik. Og udviklingen har mindet USA om, at Europa langt fra er væk fra landkortet som en kriseregion.

Krim kan derfor hurtigt blive en pyrrhussejr for Vladimir Putins Rusland. 